\title{
Insecticidal Activity of Alstonia boonei De Wild Powder against Cowpea Bruchid, Callosobruchus maculatus (Fab.) [Coleoptera: Chrysomelidae] in stored Cowpea Seeds
}

\author{
K. D. Ileke (Corresponding author) \\ Department of Environmental Biology and Fisheries, Faculty of Science \\ Adekunle Ajasin University, PMB 001, Akungba Akoko, Ondo State, Nigeria \\ Tel: 234-803-431-8706 E-mail: kayodeileke@yahoo.com \\ O. O. Odeyemi \& M. O. Ashamo \\ Department of Biology, School of Science \\ Federal University of Technology, PMB 704, Akure, Ondo State, Nigeria
}

Received: November 26, $2011 \quad$ Accepted: January 11, $2012 \quad$ Published: April 1, 2012

doi:10.5539/ijb.v4n2p125

URL: http://dx.doi.org/10.5539/ijb.v4n2p125

\begin{abstract}
The bioactivity of Alstonia boonei De Wild (Apocyanaceae) against Callosobruchus maculatus (Fab.) (Coleoptera: Chrysomelidae) in stored cowpea seeds was evaluated in the laboratory by admixing leaf, stem bark and root powders of $A$. boonei with cowpea seeds at ambient temperature of $28 \pm 2{ }^{\circ} \mathrm{C}$ and $70 \pm 5 \%$ relative humidity. The powders were incorporated into $20 \mathrm{~g}$ of cowpea seeds, Vigna unguiculata at $0.0 \%$ (control) $2.5 \%, 5.0 \%, 12.5 \%$ and $25.0 \%(\mathrm{w} / \mathrm{w})$ concentration. The ability of the plant powders to protect cowpea seeds was assessed in terms of mortality rates after 24 - 96 hours post treatment, oviposition and adult emergence, percentage weight loss and damage after the first filial generation $\left(\mathrm{F}_{1}\right)$. All the tested plant part powders significantly $(\mathrm{P}<0.05)$ reduce the longevity of adult $C$. maculatus on treated cowpea seeds. From the study, the plant powders could be ranked in order of effectiveness thus; stem bark > leaf > root. Alstonia boonei can be used as biopesticide against $C$. maculatus and its incorporation into traditional storage pest management is strongly recommended.
\end{abstract}

Keywords: Insecticidal activity, Biopesticide, Weevil Perforation Index, Synthetic insecticides, Callosobruchus maculatus, Alstonia boonei

\section{Introduction}

Cowpea bruchid, Callosobruchus maculatus (Fab.) is a major pest of wide range of stored legume seeds especially of the cowpea, Vigna unguiculata (Ofuya 2001). In many countries of Western and Central Africa, cowpea is a major dietary staple. It is often the main source of protein for the families. Cowpeas are rapidly broken down by the cowpea weevil within three to five months in storage (Ajayi \& Lale, 2000; Mbailao et al., 2006). During storage, the cowpea weevil causes heavy qualitative and quantitative losses. The damaged seeds are unsuitable for human and animal consumption and they can not be used for planting. Preservation of the quality of the seeds for the following year is one of the worrying problems of farmers. The heavy post harvest losses and quality deterioration caused by storage pests is a major problem facing agriculture in developing countries such as Nigeria (Ashamo, 2007).

The destructive activities of insects and other storage pests have been subdued by chemical control methods comprising fumigation of stored commodity with carbon disulphide, phosphine or dusting with malathion, carbaryl, pirimiphos methyl or permethrin. These chemicals have been reported to be effective against stored products pests (Ogunwolu \& Idowu, 1994; Oni \& Ileke, 2008; Adedire et al., 2011; Ileke \& Oni, 2011). In the developed countries, conventional fumigation technology is currently being scrutinised for many reasons, such as ozone depletion potential of methyl bromide and carcinogenic concerns with phosphine (Adedire et al., 2011).

The problems with many synthetic insecticides include high mammalian toxicity, high level of persistence in the environment, health hazards, residual effects, poor knowledge of application, increasing costs of application, pest 
resurgence, genetic resistance by the insect and lethal effects on non-target organisms (Ajayi \& Lale, 2000; Ashamo, 2007; Akinkurolere et al., 2009; Oni \& Ileke, 2008; Ileke \& Oni, 2011). One solution to these problems might be to totally replace synthetic chemicals with compounds, which occur naturally in plants. Most of these plant products are cheap, readily available, edible and ecologically safer means of controlling insect pest infestations of stored cereal and grains especially in the tropics (Lale, 1992; Adedire \& Ajayi, 1996; Adedire \& Lajide, 2003; Ashamo, 2007; Akinkurolere et al., 2006; 2009; Adedire et al., 2011; Ileke \& Oni, 2011).

Alstonia boonei De Wild is a medicinal plant used extensively in West and Central Africa for the treatment of malaria, fever, intestinal helminthes, snake bite, arrow poison, impotence, toothache and oedema (Terashima, 2003; Betti, 2004; Abel \& Busia, 2005; Akinmoladun et al., 2007; Ileke \& Oni, 2011). The major phytochemicals in the plant are saponin, alkaloids, tannins and cardiac glycosides (Fasola \& Egunyomi, 2005, Akinmoladun et al., 2007). Despite its popularity as a medicinal plant, the insecticidal potential of $A$. boonei has not been fully investigated has been done for other medicinal plants like neem, Azadirachta indica and Anacardium occidentale (Kilonzo, 1991; Onu \& Baba, 2003; Maina \& Lale, 2004; Adedire et al., 2011). The objective of the present study was to examine the insecticidal activities of the leaf, stem bark and root of $A$. boonei powders against the cowpea bruchid, C. maculatus, a major insect pest of cowpea and legumes (Lale \& Ofuya, 2001).

\section{Materials and Methods}

\subsection{Insect rearing}

Newly emerged adult $C$. maculatus used for this study were obtained from already existing culture in the Postgraduate Research Laboratory of the Department of Biology, Federal University of Technology, Akure, Ondo State, Nigeria. They were subsequently reared inside 1 litre Kilner jars, on uninfested cowpea seeds Vigna unguiculata variety Ife brown obtained from the Agricultural Development Programme (ADP), Ado Ekiti. Ekiti State, Nigeria. The culture was placed in an insect rearing cage at ambient temperature of $28 \pm 2{ }^{\circ} \mathrm{C}$ and $75 \pm 5 \%$ relative humidity which were monitored with the aid of a whirling thermohygrometer.

\subsection{Preparation of Alstonia boonei powders}

The plant parts of Alstonia boonei used for this study were sourced fresh from Akola farm at Igbara-Odo Ekiti, Ekiti State, Nigeria. These plant materials were dried in an open laboratory and ground into very fine powder using an electric blender (Supermaster ${ }^{\circledR}$, Model SMB 2977, Japan). The powders were further sieved to pass through $1 \mathrm{~mm}^{2}$ perforation (Ileke \& Oni, 2011). The powders were packed in plastic containers with tight lids and stored in a refrigerator at $4^{0} \mathrm{C}$ prior to use.

\subsection{Collection of cowpea seeds}

Cowpea, Vigna unguiculata variety Ife brown obtained from newly stock cowpea seeds free of insecticides at Agricultural Development Programme (ADP), Ado Ekiti. Ekiti State, Nigeria, was used for this study. The cowpea were first cleaned and disinfested by keeping them in a freezer at $-5^{\circ} \mathrm{C}$ for 7 days to kill all hidden infestations. The disinfested seeds were then dried in a Gallenkamp oven (Model 250) at $40^{\circ} \mathrm{C}$ for 4 hours (Jambere et al., 1995) before they were stored in plastic containers with tight lids disinfested by swabbing with $90 \%$ alcohol.

\subsection{Insect bioassay}

Leaf, stem bark and root powders were admixed with $20 \mathrm{~g}$ of cowpea seed at $2.5,5.0,12.5$ and $25.0 \% \mathrm{w} / \mathrm{w}$ concentration (Fatope et al., 1995) in $250 \mathrm{ml}$ plastic containers. The seeds in the controls contained no plant powders. The containers with their contents were gently shaken to ensure thorough admixture of the cowpea seeds and treatment powders. Ten pairs of day-old adults C. maculatus were introduced to each of the containers and covered. The insects were sexed following the reports of Odeyemi \& Daramola (2000). Three replicates of the treated and untreated controls were laid out in Complete Randomized Design. The adult mortality was assessed after every 24 hours for 96 hours. Adults were considered dead when probed with sharp objects and there were no responses. On day 5 , all insects, both dead and alive, were removed from each container and ovipositions were noted before returning the seeds to their respective containers. Progeny emergence $\left(\mathrm{F}_{1}\right)$ was then recorded at 5 weeks. The containers were sieved out and newly emerged adult bruchid were counted with an aspirator. The percentage adult emergence was calculated using the method of Odeyemi \& Daramola (2000).

At week 6 , the cowpea were re-weighed by using Metler weighing balance and the $\%$ loss in weight was determined using the method of Odeyemi \& Daramola (2000).

After re-weighing, the numbers of damaged cowpea were evaluated by counting wholesome and bored or seed with bruchid emergent holes. Percentage of seed damaged was also computed using the method of FAO (1985). 
Weevil Perforation Index (WPI) was adopted from the analysis of damage using the method of Fatope et al. (1995), Adedire \& Ajayi, 1996. The weevil perforation is define as follows:

$$
\mathrm{WPI}=\frac{\% \text { treated cowpea seeds perforated }}{\% \text { control cowpea seeds perforated }} \times \frac{100}{1}
$$

\subsection{Statistical analysis}

Data were subjected to analysis of variance and where significant differences existed, treatment means were separated using the New Duncan's Multiple Range Test (Zar, 1984).

\section{Results}

\subsection{Effect of alstonia boonei powder on adult mortality of C. maculatus}

The stem bark powder was able to caused $100 \%$ mortality of adult C. maculatus within 72 hours of application. Leaf, stem bark and root powders of Alstonia boonei tested at 5\% level showed similar bioactivity against Callosobruchus maculatus after 96 hours of post treatment. All the tested plant parts powders significantly $(\mathrm{P}<0.05)$ reduce adult $C$. maculatus on treated cowpea seeds (Table 1$)$. There was a significant difference $(\mathrm{P}<0.05)$ in mortality of adult insects amongst the treatments, with stem bark powder causing $100 \%$ mortality of adult $C$. maculatus at all tested concentrations after 72 hours of application. This was followed by leaf powder at 5.0, 12.5 and $25 \% \mathrm{w} / \mathrm{w}$ concentration evoking $100 \%$ mortality of $C$. maculatus after 96 hours of exposure. Root powder of $A$. boonei was the least toxic causing $100 \%$ bruchid mortality after 96 hours of post treatment at $25 \% \mathrm{w} / \mathrm{w}$ concentration.

\subsection{Effect of alstonia boonei powder on oviposition and adult emergence of C. maculatus}

All the plant parts powders effectively reduced oviposition by C. maculatus (Table 2). The number of eggs laid by C. maculatus on treated cowpea seeds was significantly $(\mathrm{P}>0.05)$ lower than number of eggs laid on untreated cowpea seeds. There was no significant difference $(\mathrm{P}<0.05)$ in the mean number of eggs laid on the treated cowpea seeds with leaf, stem bark and root powders of $A$. boonei. The percentage adult emergence in the untreated seeds was significantly different $(\mathrm{P}>0.05)$ from emergence in the treated cowpea seeds. No progeny production took place in cowpea seeds treated with stem bark powder (Table 2). However, there was adult emergence in cowpea seeds treated with leaf powder at $2.5 \% \mathrm{w} / \mathrm{w}$ concentration and root powder at 2.5 and $5 \% \mathrm{w} / \mathrm{w}$ concentration on treated cowpea seeds. These did not show any significant difference $(\mathrm{P}<0.05)$ when compared with other treated seeds.

\subsection{Protectantability of alstonia boonei powder on cowpea seeds}

Leaf, stem bark and root powders of $A$. boonei completely prevented infestation and damage of the treated cowpea seeds (Table 3). There was no significant difference $(\mathrm{P}<0.05)$ in seeds damage, weight loss and Weevil Perforation Index (WPI) in the treated cowpea seeds. However, the Weevil Perforation Index (WPI) of 8.7 at $2.5 \% \mathrm{w} / \mathrm{w}$ concentration and 11.47 and 4.3 at 2.5 and $5 \% \mathrm{w} / \mathrm{w}$ concentration obtained for leaf and root powders of $A$. boonei respectively were significantly different $(\mathrm{P}>0.05)$ from Weevil Perforation Index WPI of the control. The untreated cowpea seeds recorded $73.93 \%$ damage as revealed by emergent holes of the bruchid. The weight of untreated cowpea seeds was significantly $(\mathrm{P}>0.05)$ reduced compared with treated cowpea seeds.

\section{Discussion}

The high mortality rate of adults $C$. maculatus recorded on cowpea seeds treated with leaf, stem bark and root powders of A. boonei could be due to high toxic effect of the plant parts on adult C. maculatus. Stem bark powder of $A$. boonei prevented the emergence of $C$. maculatus adults, an effect that is in agreement with the observation of Oigiangbe et al. (2007) who reported that aqueous extracts of the stem bark of $A$. boonei adversely affected the longevity of Maruca vitrata. Our present observations also corroborate the report of Osawe et al. (2007) who reported that the aqueous extracts of the stem bark and leaves of $A$. boonei adversely affected the survival and growth of Sesamia calamists. The result of this investigation are also similar to the observations of Ileke \& Oni (2011) who obtained 100\% mortality of adult Sitophilus zeamais in wheat grains treated with A. boonei stem bark powder.

The lethal effect of the stem bark powder on the bruchid could be as a result of contact toxicity. Insects breathe by means of trachea that usually open at the surface of the body through spiracles (Adedire et al., 2011). The spiracle might have been blocked by the plant powders thereby leading to suffocation of adult bruchids. These toxic effect has been attributed by various authors to the presence of some chemical compounds of the triterpenoids and indole 
alkaloid group such as alstonine, astonidine and porphine that have been identified from the stem bark of $A$. boonei (Phillipson et al., 1987; Anonymous, 1992; 2001).

The plant powders also prevented oviposition, adult emergence, reduction in weight loss and seeds damage by $C$. maculatus on treated cowpea seeds. These powders inhibits locomotion which affect mating activities and sexual communication as well as deterring females from laying eggs, as well as complete suppression of the developmental stages of insects which have been reported by a number of authors (Ivbijaro \& Agbaje, 1986;Ofuya, 1992; Okonkwo \& Okoye, 1996; Adedire 2002; Maina \& Lale, 2004; Mbailao et al., 2006, Akinkurolere et al., 2006, Okosun \& Adedire, 2010; Adedire et al., 2011; Ileke \& Oni, 2011). The protectantability of the plant powders were highly remarkable.

\section{Conclusion}

It is evident from this study that all the plant-part powders tested have the potential of being used as biopesticides. Higher concentration of the leaf and root powders could be more effective since it is expected to contain high active components. Further research still needs to be carried out on oil extracts of $A$. boonei which will reduce the bulkiness of the powders when used for control of pests in bags or in storage bins since their potential as biopesticides against stored products insects appears great.

\section{Acknowledgments}

The authors were grateful to Mr. Theophilus Ileke, the father of the first author who highlighted the medicinal values of the plant.

\section{References}

Abel, C., \& Busia, K. (2005). An exploratory ethnobotanical study of the practice of herbal medicine by the Akan peoples of Ghana (Ethnobotanical Study: Herbal medicine in Ghana). pp. 42.

Adedire, C. O., \& Ajayi, T. S. (1996). Assessment of the insecticidal properties of some plant extracts as grain protection against the maize weevil, Sitophilus zeamais. Nigerian Journal of Entomology, 13, 93-101.

Adedire, C. O., \& Lajide, L. (2003). Ability of extract of ten tropical plant species to protect maize grains against infestation by the maize weevil Sitophilus zeamais during storage. Nigerian Journal of Experimental Biology, 4(2), 175-179.

Adedire, C. O. (2002). Use of nutmeg, Myristica fragrans (Houtt) powder and oil for the control of cowpea storage bruchid. Callosobruchus maculatus. Journal of Plant Diseases and Protection, 109, 193-199.

Adedire, C. O., Obembe, O. O., Akinkurolele, R. O., \& Oduleye, O. (2011). Response of Callosobruchus maculatus (Coleoptera: Chysomelidae: Bruchidae) to extracts of cashew kernels. Journal of Plant Diseases and Protection, 118(2), 75-79.

Ajayi, F. A., \& Lale, N. E. S. (2001). Susceptibility of unprotected seeds and seeds of local bambara groundnut cultivars protected with insecticidal essential oils to infestation by Callosobruchus maculatus (F.). Journal of Stored Products Research, 37, 47-62. http://dx.doi.org/10.1016/S0022-474X(00)00006-0

Akinkurolere R. O, Sebastien B, Haoliang C., \& Hongyu Z, (2009). Parasitism and host location preference in Habrobracon hebetor (Hymenoptera: Braconidae): Role of refuge, choice and host instar. Journal of Economic Entomology, 102(2), 610-615. http://dx.doi.org/10.1603/029.102.0219

Akinkurolere, R. O., Adedire, C. O., \& Odeyemi, O. O. (2006). Laboratory evaluation of the toxic properties of forest anchomanes, Anhomanes difformis, against pulse beetle, Callosobruchus maculatus (Coleoptera: Bruchidae). Insect Science, 13, 25-29. http://dx.doi.org/10.1111/j.1744-7917.2006.00064.x

Akinmoladun, A. C., Ibukun, E. O., Afor, E., Akinrinlola, B. L., Onibon, T. R., Akinboboye, A. O., Obuotor, E. M., \& Farombi, E. O. (2007). Chemical constituents and antioxidant activity of Alstonia boonei. African Journal of Biotechnology, 6(10), 1197-1201.

Anonymous, (1992). Ghana Herbal Pharmacopoeia. The advent press. Monograph of Alstonia bark, pp 10-12.

Anonymous. (2001). Earthnotes Herb Library. Esnestinar Parziale CH.

Ashamo, M. O. (2007). Evaluation of contact toxicity and fumigant effect of some plant powders against Sitophilus zeamais (Mots.). Proceedings of the Akure- Humboldt Kellong ( ${ }^{\text {rd }}$ SAAT Annual Conference: Medicinal plants in Agriculture, The Nigeria Experience, pp. 64-67.

Betti, J. L. (2004). An ethnobotanical study of medicinal plants among the Baka Pygmies in the dja biosphere reserve, Cameroon. African Study Monographs, 24, 1-27. 
FAO. (1985). Prevention of Post harvest food losses. Training Series No. 10 (122). Food and Agriculture Organisation of the United Nation, Rome, p. 120.

Fasola, T. R., \& Egunyomi, A. (2005). Nigerian usage of bark in phytomedicine. Ethnobotanical Research and Applications, 3, 73-77.

Fatope, M. O., Mann, A., \& Takeda, Y. (1995). Cowpea weevil bioassay: A simple prescreen for plants with grain protectant effects. International Journal of Pest Management, 41, 44-86. http://dx.doi.org/10.1080/09670879509371928

Ileke, K. D., \& Oni, M. O. (2011). Toxicity of some plant powders to maize weevil, Sitophilus zeamais (Coleoptera: Curculionidae) on stored wheat grains. African Journal of Agricultural Research, 6(13), 3043-3048.

Ivbijaro, M. F., \& Agbaje, M. (1986). Insecticidal activities of Piper guineense and Capsicum species in cowpea bruchid, Callosobruchus Maculatus. Insect sci. Appl., 7, 521-524.

Jambere, B., Obeng-Ofori, D., \& Hassanali, A. (1995). Products derived from the leaves of Ocimum kilmandsharicum as post harvest grain protestant against the infection of three major stored insect product pests. Bulletin of Entomological Research, 85, 351-367.

Kilonzo, B. S. (1991). Larvicidal effects of neem, Azadirachta indica on fleas in Tanzania. Insect Science and its Application, 12(5, 6), 699-702.

Lale, N. E. S., \& Ofuya, T. I. (2001). Overview of pests problems and control in the tropical storage environment. In: Ofuya T.I. and Lale, N. E. S. (eds) pest of stored cereals and pulses in Nigeria. Dave Collins publications, Nigeria. PP 1-23.

Lale, N. E. S. (1992). A laboratory study of the comparative toxicity of products from three spices to the maize weevil, Sitophilus zeamais. Postharvest Biology Technology, 2, 61-64. http://dx.doi.org/10.1016/0925-5214(92)90028-N

Maina, Y. T., \& Lale, N. E. S. (2004). Efficacy of integrating varietal resistance and neem (Azadirachta indica) seed oil for the management of Callosobruchus maculatus infesting Bambara Groundnut in storage in storage. Nigerian Journal of Entomology, 2, 94-103.

Mbailao, M., Nanadoum, M., Automne, B., Gabra, B., \& Emmanuel, A. (2006). Effect of six common seed oils on survival, egg lying and development of the cowpea weevil, Callosobruchus maculatus. Journal of Biological Science, 6 (2), 420 -425. http://dx.doi.org/10.3923/jbs.2006.420.425

Odeyemi, O. O., \& Daramola, A. M. (2000). Storage practices in the tropics: Food storage and pest problems. First Edition, Dave Collins Publication, Nigeria, Vol. 1, 235.

Ofuya, T. I. (1992). Oviposition deterrence and ovicidal properties of some plant powders against C. maculatus in stored cowpea seeds. Journal of Agricultural Science, $115, \quad 343-345$. http://dx.doi.org/10.1017/S0021859600075766

Ofuya, T. I. (2001). Biology, Ecology and control of insect pests of stored Food legumes. In: pp 59-94. Ofuya T. I., \& Lale, N. E. S. (eds) pest of stored cereals and pulses in Nigeria. Dave Collins publications, Nigeria, PP 25-58.

Ogunwolu, E. O., \& Idowu, O. (1994). Potential of powdered Zanthoxylum zanthoxylloides root bark and Azadirachta indica seed for the control of the of cowpea seed bruchid. Callosobruchus maculatus. Nigeria Journal of African Zoology, 108, 521-528.

Oigiangbe, O. N., Igbinosa, I. B. \& Tamo, M. (2007). Bioactivity of extracts of Alstonia boonei De Wild stem bark against Maruca vitrata (Lepidoptera: Pyralidae). Advances in Science and Technology, 1(1), 67-70.

Okonkwo, E. U., \& Okoye, W. I. (1996). The efficacy of four seed powders and the essential oils as protestants of cowpea and maize grains against infestation by Callosobruchus maculatus and Sitophilus zeamais Nigeria International Journal Pest Management, 42 (3), 143-146. http://dx.doi.org/10.1080/09670879609371985

Okosun, O. O., \& Adedire, C. O. (2010). Potency to cowpea seed bruchid, Callosobruchus maculatus of African Nutmeg seed, Monodora myristica extracted with different solvents. Nigerian Journal Entomology, 27, 89-95.

Oni, M.O., \& Ileke, K.. D. (2008). Fumigant toxicity of four botanical plant oils on survival, egg laying and progeny development of the dried yam beetle, Dinoderus porcellus (Coleoptera: Bostrichidae) Ibadan Journal of Agricultural Research, 4 (2), 31-36.

Osawe, N. O., Igho, B. I., \& Manuele, T. (2007). Insecticidal activity of the medicinal plant, Alstonia boonei against Sesamia calamistis Hampson. Journal of Zhejiang University B, 8 (10), 752 - 755. 
Onu, I., \& Baba, G. O. (2003). Evaluation of neem products for the control of Dermestid beetle on dried fish. Nigerian Journal of Entomology, 20,105-115.

Phillipson, J. D., O’ Neill, M. J., Wright, C. W., Bray, D. H., \& Warhaurst, D. C. (1987). Plants as a sources of Antimalaria and Amoebicidal Compound; Medicinal and poisonous plants of the Tropics: Proceedings of symposium 5 - 35 of the $14^{\text {th }}$ International Botanical Congress Berlin, Pp 70-78.

Terashima, H. N. (2003). Use and attribute of plants and animals among the Ituri forest foragers; a comparative ethnobatanical and ethnozoological study. African Study Monographs. 28(supplementary), 7-24.

Zar, J. H. (1984). Biostatatical Analysis, $2^{\text {nd }}$ edition, Prentice- Hall International, Englewood Cliffs, N. J.

Table 1. Mortality of adult Callosobruchus maculatus in cowpea seeds treated with Alstonia boonei powders

\begin{tabular}{|c|c|c|c|c|c|}
\hline \multirow{2}{*}{$\begin{array}{l}\text { Plant part } \\
\text { powders }\end{array}$} & \multirow[t]{2}{*}{ Conc. $\mathrm{w} / \mathrm{w}$} & \multicolumn{4}{|c|}{ Mean $\%$ mortality \pm S. E. at $24 \mathrm{~h}$ to $96 \mathrm{~h}$ Post Treatment } \\
\hline & & $24 \mathrm{~h}$ & $48 \mathrm{~h}$ & $72 \mathrm{~h}$ & $96 \mathrm{~h}$ \\
\hline \multirow[t]{4}{*}{ Leaf } & 2.5 & $10.00 \pm 0.00^{\mathrm{a}}$ & $30.00 \pm 0.00^{\mathrm{c}}$ & $57.68 \pm 0.41^{\mathrm{c}}$ & $77.67 \pm 0.32^{\mathrm{bc}}$ \\
\hline & 5.0 & $27.03 \pm 0.05^{\mathrm{b}}$ & $45.01 \pm 0.20^{\mathrm{d}}$ & $78.45 \pm 0.30^{\mathrm{d}}$ & $100.00 \pm 0.00^{\mathrm{e}}$ \\
\hline & 12.5 & $42.03 \pm 0.05^{\mathrm{de}}$ & $76.30 \pm 0.06^{\mathrm{fg}}$ & $100.00 \pm 0.00^{\mathrm{f}}$ & $100.00 \pm 0.00^{\mathrm{e}}$ \\
\hline & 25.0 & $50.06 \pm 0.75^{\mathrm{e}}$ & $82.71 \pm 0.30^{\text {gh }}$ & $100.00 \pm 0.00^{\mathrm{f}}$ & $100.00 \pm 0.00^{\mathrm{e}}$ \\
\hline \multirow[t]{4}{*}{ Stem bark } & 2.5 & $30.00 \pm 0.00^{\mathrm{bc}}$ & $70.26 \pm 0.25^{\mathrm{f}}$ & $100.00 \pm 0.00^{f}$ & $100.00 \pm 0.00^{\mathrm{e}}$ \\
\hline & 5.0 & $38.21 \pm 0.58^{\mathrm{cd}}$ & $87.31 \pm 0.67^{\mathrm{h}}$ & $100.00 \pm 0.00^{\mathrm{f}}$ & $100.00 \pm 0.00^{\mathrm{e}}$ \\
\hline & 12.5 & $50.48 \pm 0.17^{\mathrm{e}}$ & $100.00 \pm 0.00^{\mathrm{i}}$ & $100.00 \pm 0.00^{\mathrm{f}}$ & $100.00 \pm 0.00^{\mathrm{e}}$ \\
\hline & 25.0 & $70.26 \pm 0.25^{\mathrm{f}}$ & $100.00 \pm 0.00^{\mathrm{i}}$ & $100.00 \pm 0.00^{\mathrm{f}}$ & $100.00 \pm 0.00^{\mathrm{e}}$ \\
\hline \multirow[t]{4}{*}{ Root } & 2.5 & $0.00 \pm 0.00^{\mathrm{a}}$ & $20.00 \pm 0.00^{\mathrm{b}}$ & $45.01 \pm 0.20^{\mathrm{b}}$ & $67.30 \pm 0.56^{\mathrm{b}}$ \\
\hline & 5.0 & $10.00 \pm 0.00^{\mathrm{a}}$ & $30.00 \pm 0.00^{\mathrm{b}}$ & $60.00 \pm 0.00^{\mathrm{c}}$ & $87.70 \pm 0.30^{\mathrm{cd}}$ \\
\hline & 12.5 & $24.64 \pm 0.30^{\mathrm{b}}$ & $63.33+0.01^{\mathrm{e}}$ & $87.70 \pm 0.30^{\text {de }}$ & $96.67 \pm 0.32^{\mathrm{de}}$ \\
\hline & 25.0 & $45.01 \pm 0.20^{\mathrm{de}}$ & $84.31 \pm 0.67^{\text {gh }}$ & $90.01 \pm 0.02^{\text {ef }}$ & $100.00 \pm 0.00^{\mathrm{e}}$ \\
\hline Control & 0.00 & $0.00 \pm 0.00^{\mathrm{a}}$ & $0.00 \pm 0.00^{\mathrm{a}}$ & $0.00 \pm 0.00^{\mathrm{a}}$ & $0.00 \pm 0.00^{\mathrm{a}}$ \\
\hline
\end{tabular}

Each value is a mean of \pm standard error of three replicates. Means within the same column followed by the same letter(s) are not significantly different at $(\mathrm{P}>0.05)$ from each other using New Duncan Multiple Range Test.

Table 2. Effect of Alstonia boonei powders on oviposition and adult emergence of Callosobruchus maculatus

\begin{tabular}{|c|c|c|c|}
\hline Plant part powders & Conc. $\mathrm{w} / \mathrm{w}$ & No of Eggs & \% Adults Emergence \\
\hline \multirow{3}{*}{ Leaf } & 2.5 & $30.33 \pm 0.01^{\mathrm{c}}$ & $19.78 \pm 0.40^{\mathrm{bc}}$ \\
\cline { 2 - 4 } & 5.0 & $10.33 \pm 0.01^{\mathrm{a}}$ & $0.00 \pm 0.00^{\mathrm{a}}$ \\
\cline { 2 - 4 } & 12.5 & $10.00 \pm 0.00^{\mathrm{a}}$ & $0.00 \pm 0.00^{\mathrm{a}}$ \\
\cline { 2 - 4 } & 25.0 & $10.00 \pm 0.00^{\mathrm{a}}$ & $0.00 \pm 0.00^{\mathrm{a}}$ \\
\cline { 2 - 4 } & 2.5 & $10.33 \pm 0.01^{\mathrm{a}}$ & $0.00 \pm 0.00^{\mathrm{a}}$ \\
\cline { 2 - 4 } & 5.0 & $10.33 \pm 0.01^{\mathrm{a}}$ & $0.00 \pm 0.00^{\mathrm{a}}$ \\
\cline { 2 - 4 } & 12.5 & $10.00 \pm 0.00^{\mathrm{a}}$ & $0.00 \pm 0.00^{\mathrm{a}}$ \\
\hline \multirow{4}{*}{ Stem bark } & 25.0 & $10.00 \pm 0.00^{\mathrm{a}}$ & $0.00 \pm 0.00^{\mathrm{a}}$ \\
\cline { 2 - 4 } & 2.5 & $40.33 \pm 0.01^{\mathrm{c}}$ & $24.79 \pm 0.41^{\mathrm{c}}$ \\
\cline { 2 - 4 } & 5.0 & $16.67 \pm 0.32^{\mathrm{b}}$ & $12.06 \pm 0.10^{\mathrm{b}}$ \\
\cline { 2 - 4 } & 12.5 & $10.33 \pm 0.01^{\mathrm{a}}$ & $0.00 \pm 0.00^{\mathrm{a}}$ \\
\cline { 2 - 4 } & 25.0 & $81.47 \pm 0.20^{\mathrm{a}}$ & $84.09 \pm 0.20^{\mathrm{a}}$ \\
\hline
\end{tabular}

Each value is a mean of \pm standard error of three replicates. Means within the same column followed by the same letter(s) are not significantly different at $(\mathrm{P}>0.05)$ from each other using New Duncan Multiple Range Test. 
Table 3. Protectantability of Alstonia boonei powders on cowpea seeds

\begin{tabular}{|c|c|c|c|c|c|c|}
\hline $\begin{array}{c}\text { Plant part } \\
\text { powders }\end{array}$ & Conc. w/w & $\begin{array}{c}\text { Mean total no } \\
\text { of seeds }\end{array}$ & $\begin{array}{c}\text { Mean no of } \\
\text { damaged } \\
\text { seeds }\end{array}$ & $\begin{array}{c}\text { Mean \% seed } \\
\text { damaged }\end{array}$ & $\%$ weight loss & $\begin{array}{l}\text { *Weevil } \\
\text { Perforation } \\
\text { Index (WPI) }\end{array}$ \\
\hline \multirow{3}{*}{ Leaf } & 2.5 & 93.33 & $6.00 \pm 0.00^{\mathrm{a}}$ & $6.43 \pm 0.46^{\mathrm{a}}$ & $0.80 \pm 0.00^{\mathrm{a}}$ & $8.70 \pm 0.33^{\mathrm{a}}$ \\
\cline { 2 - 7 } & 5.0 & 93.67 & $0.00 \pm 0.00^{\mathrm{a}}$ & $0.00 \pm 0.00^{\mathrm{a}}$ & $0.00 \pm 0.00^{\mathrm{a}}$ & $0.00 \pm 0.00^{\mathrm{a}}$ \\
\cline { 2 - 7 } & 12.5 & 94.33 & $0.00 \pm 0.00^{\mathrm{a}}$ & $0.00 \pm 0.00^{\mathrm{a}}$ & $0.00 \pm 0.00^{\mathrm{a}}$ & $0.00 \pm 0.00^{\mathrm{a}}$ \\
\cline { 2 - 7 } & 25.0 & 94.67 & $0.00 \pm 0.00^{\mathrm{a}}$ & $0.00 \pm 0.00^{\mathrm{a}}$ & $0.00 \pm 0.00^{\mathrm{a}}$ & $0.00 \pm 0.00^{\mathrm{a}}$ \\
\hline \multirow{3}{*}{ Stem bark } & 2.5 & 94.33 & $0.00 \pm 0.00^{\mathrm{a}}$ & $0.00 \pm 0.00^{\mathrm{a}}$ & $0.00 \pm 0.00^{\mathrm{a}}$ & $0.00 \pm 0.00^{\mathrm{a}}$ \\
\cline { 2 - 7 } & 5.0 & 94.33 & $0.00 \pm 0.00^{\mathrm{a}}$ & $0.00 \pm 0.00^{\mathrm{a}}$ & $0.00 \pm 0.00^{\mathrm{a}}$ & $0.00 \pm 0.00^{\mathrm{a}}$ \\
\cline { 2 - 7 } & 12.5 & 93.33 & $0.00 \pm 0.00^{\mathrm{a}}$ & $0.00 \pm 0.00^{\mathrm{a}}$ & $0.00 \pm 0.00^{\mathrm{a}}$ & $0.00 \pm 0.00^{\mathrm{a}}$ \\
\cline { 2 - 7 } & 25.0 & 94.33 & $0.00 \pm 0.00^{\mathrm{a}}$ & $0.00 \pm 0.00^{\mathrm{a}}$ & $0.00 \pm 0.00^{\mathrm{a}}$ & $0.00 \pm 0.00^{\mathrm{a}}$ \\
\hline \multirow{3}{*}{ Root } & 2.5 & 94.33 & $8.00 \pm 0.00^{\mathrm{a}}$ & $8.48 \pm 0.65^{\mathrm{a}}$ & $10.40 \pm 0.20^{\mathrm{a}}$ & $11.47 \pm 0.70^{\mathrm{b}}$ \\
\cline { 2 - 7 } & 5.0 & 94.33 & $3.00 \pm 0.00^{\mathrm{a}}$ & $3.18 \pm 0.20^{\mathrm{a}}$ & $5 . .67 \pm 0.40^{\mathrm{a}}$ & $4.30 \pm 0.60^{\mathrm{a}}$ \\
\cline { 2 - 7 } & 12.5 & 94.33 & $0.00 \pm 0.00^{\mathrm{a}}$ & $0.00 \pm 0.00^{\mathrm{a}}$ & $0.00 \pm 0.00^{\mathrm{a}}$ & $0.00 \pm 0.00^{\mathrm{a}}$ \\
\cline { 2 - 7 } & 25.0 & 93.33 & $0.00 \pm 0.00^{\mathrm{a}}$ & $0.00 \pm 0.00^{\mathrm{a}}$ & $0.00 \pm 0.00^{\mathrm{a}}$ & $0.00 \pm 0.00^{\mathrm{a}}$ \\
\hline Control & 0.00 & 93.33 & $69.0 \pm 0.00^{\mathrm{b}}$ & $73.93 \pm 1.20^{\mathrm{b}}$ & $83.47 \pm 0.70^{\mathrm{b}}$ & $50.00 \pm 0.00^{\mathrm{c}}$ \\
\hline
\end{tabular}

Each value is a mean of \pm standard error of three replicates. Means within the same column followed by the same letter(s) are not significantly different at $(\mathrm{P}>0.05)$ from each other using New Duncan Multiple Range Test.

*Weevil Perforation Index (WPI). Value lower than 50 is an index of positive protectant effect while WPI greater than 50 is an index of negative protectantability. 